\title{
ІННОВАЦІЙНА ДИФУЗІЯ В ОРГАНІЗАЦІЇ РЕСТОРАННОГО ГОСПОДАРСТВА ПІД ВПЛИВОМ ПАНДЕМІЇ COVID-19
}

\section{INNOVATIVE DIFFUSION IN THE ORGANIZATION OF THE RESTAURANT INDUSTRY UNDER THE INFLUENCE OF THE COVID PANDEMIC19}

\author{
Компанець Катерина Андріївна \\ кандидат економічних наук, доцент, \\ Київський національний торгово-економічний університет \\ ORCID: https://orcid.org/0000-0002-7189-2355 \\ Антонюк Ірина Юріївна \\ кандидат технічних наук, доцент, \\ Київський національний торгово-економічний університет \\ ORCID: https://orcid.org/0000-0003-4629-3403 \\ Медведєва Анжеліка Олександрівна \\ кандидат технічних наук, доцент, \\ Київський національний торгово-економічний університет \\ ORCID: https://orcid.org/0000-0002-7991-9161
}

\section{Kompanets Kateryna, Antoniuk Iryna, Medvedieva Anzhelika Kyiv National University of Trade and Economics}

В статті розкриті питання сучасного стану діяльності підприємств ресторанного господарства. Визначені основні критичні зміни в зовнішньому та внутрішньому середовищі підприємств гостинності. Визначені наслідки що були спричинені пандемією COVID-19. Досліджено роботи наукової спільноти, щодо питань діяльності підприємств ресторанного господарства. Саме це стало підставами визначення мети та завдання наукового дослідження. В статті надається оцінювання наукового бачення інноваційних дифузій організаційної діяльності підприємств ресторанного господарства. Визначені передумови застосування кожної гіпотези та встановлено, що в сучасних кризисних умовах підприємства ресторанного господарства знаходиться на першому рівні інноваційної дифрузії. На підставі цього була запропонована програма інноваційної дифрузної організації ресторанного господарства з елементами фокусування.

Ключові слова: інновація, організація, підприємства ресторанного господарства, інноваційна дифузія, пандемія COVID-19.

В статье раскрыты вопросы современного состояния предприятий ресторанного хозяйства. Определены основные критические изменения во внешней и внутренней среде ресторанного бизнеса. Определены последствия, которые были вызваны пандемией COVID-19. Исследованы работы научного сообщества, по вопросам деятельности предприятий ресторанного хозяйства. Это послужило основанием определения цели и задачи научного исследования. В статье приводится оценка научного видения инновационных диффоузий, которые дают возможность в усовершенствовании организационной деятельности предприятий ресторанного хозяйства. Определены предпосылки применения каждой гипотезы и установлено, что в современных кризисных условиях предприятия ресторанного хозяйства находится на первом уровне инновационной дисрфузии. На основании этого была предложена программа инновационной дифффузной организации ресторанного хозяйства с элементами фокусировки.

Ключевые слова: инновация, организация, предприятия ресторанного хозяйства, инновационная дифрфузия, пандемия COVID-19.

The article reveals the current state of activity of restaurant enterprises. The main critical changes in the external and internal environment of hospitality enterprises are identified. The consequences of the Covid pandemic19 have been identified. Quarantine has led to the fact that a large number of employees in the restaurant industry have be- 
come unemployed. This is because not all cafes and restaurants have survived the two-month crisis. The works of the scientific community on the issues of activity of restaurant enterprises are investigated. However, attention is not fully paid to the areas and measures to ensure the reliability of enterprises during quarantine restrictions. Therefore, these objective definitions of the issue provided the basis for further scientific understanding of the application of innovative diffusion in the organization of the restaurant industry in Ukraine during the Covid pandemic19. The article provides an assessment of the scientific vision of innovative diffusions, which provide an opportunity in the organizational activities of restaurant enterprises. According to the scientific view, there are four levels of diffuse management of the restaurant business. First-level business restaurant enterprises consider the organization of the management staff as an internal neutral element of potential, and the role of the manager is limited to the establishment of production, regardless of the problems of competitiveness and support. This position is not relevant enough and does not fit into the modern realities of the world. The preconditions for the application of each hypothesis are determined and it is established that in the modern crisis conditions the restaurant enterprise is at the first level of innovative diffusion. Based on this, a program of innovative diffuse organization of the restaurant industry with elements of focus was proposed. This program is based on the basic modern realities society and based on the involvement of all consumers. The implementation of CRM systems for feedback is an important direction in the implementation of the program of innovative diffuse organization of the restaurant industry with elements of focus.

Keywords: innovation, organization, restaurant enterprises, innovative diffusion, Covid pandemic19.

Постановка проблеми. Сучасні умови кризисних економічних процесів, постійних змінних параметрів зовнішнього середовища, різкого загострення фрінансово-економічної кризи в крані $є$ наслідками карантинних обмежень в світі через пандемію COVID-19. До початку коронавірусу в Україні було понад 30000 закладів громадського харчування. В середньому, в одному працювало 35 осіб. Карантин призвів до того, що велика кількість співробітників ресторанної сорери стала безробітною. Це сталося через те, що не всі кафе та ресторани пережили двомісячну кризу [2]. Тому особливий науковий і практичний інтерес набуває проблема срормування стратегічного потенціалу підприємств ресторанного господарства та стає за необхідне пошук шляхів досягнення стійких конкурентних позицій, використовуючи напрямки переорганізації ресторанного господарства та інструментів посилення свого стратегічного потенціалу.

Аналіз останніх досліджень і публікацій. Критичний аналіз наукових праць з окресленої проблематики засвідчив, що питання організації ресторанного господарства, пошук нових стратегічних ідей все частіше стають предметом сучасних наукових праць. Результати фрундаментальних системних досліджень висвітлюються у працях Азоєва Г., Ансофрфра І., Балабанової Л., Вітряк О., Гніцевич В., Градова А., Іванова Ю., Коваленко Л., Ламбена Ж., Мазаракі А., Райзберга Б., Смоліна І., Уотермана Р., Федорова Д., Чернеги О., Юдина Т. та інших. При цьому питання, що стосуються специфріки фрормування інноваційного мислення в управління підприємств ресторанного господарства, досліджені на низькому рівні. Проблем закладів ресторанного бізнесу в ракурсі діяльності підприємств під час пандемічної кризи охопило цікавість наукового світу і стало однією 3 головною темою досліджень вчених, таких як Бовш Л., Гопкало Л., Горбенко Ю., Джордж Г., Комарницький І., Лахані К., Литвишко Л., Пуранам П. Але не в повній мірі приділяється увага напрямків та заходів забезпечення надійності діяльності підприємств під час карантинних обмежень. Тому саме ці об'єктивні визначення проблематики дали підстави для подальшого наукового осмислення питань застосування інноваційної дифрузії в організації ресторанного господарства в Україні під час пандемії COVID-19.

Формулювання цілей статті. Метою статті $€$ обґрунтування особливостей інноваційного розвитку організації ресторанного господарства під впливом пандемії Covid19

Досягнення мети статті передбачає вирішення таких завдань:

- розглянути сучасний стан діяльності підприємств ресторанного господарства;

- охарактеризувати стратегічний потенціал та конкурентні переваги в ресторанному бізнесі в сучасних пандемічних умовах;

- провести оцінювання наукового бачення інноваційних дифрузій організаційної діяльності підприємств ресторанного господарства;

- визначити шляхи оптимізації стратегічної направленості підприємств ресторанного господарства, щодо виходу з пандемічної кризи;

- здійснити обґрунтування програми інноваційної дисрузії організації ресторанного господарства.

Виклад основного матеріалу дослідження. Окреме підприємство ресторанного господарства не є єдиним продавцем послуг. В ході своєї діяльності воно стає учасником конкурентної боротьби за споживача (клієнта). 
Тому одним з важливих етапів сучасної інноваційної діяльності $€$ срормування стратегічного потенціалу. Успішний розвиток підприємства ресторанного бізнесу неможливий без фрормування ефрективної організаційної моделі ресторанного господарства. Це полягає передусім у виявленні сильних і слабких місць підприємства ресторанного господарства, аналізі конкурентної стратегії, що дає можливість виявити основні резерви підвищення стратегічного потенціалу. Це в умовах карантинних обмеженнях стає все далі тяжче. Так як показує останнє дослідження Poster за піврічний період встановлено, що за чотири тижні квітня-травня падіння обігу у невеликих ресторанів середнього і невисокого сегменту склала в середньому 58\%, у барів - 53\% в порівнянні з чотирма тижнями до карантину. Бургерні і касре втратили 45\% і 43\% відповідно. Кав'ярні за цей період в середньому втратили 12\% від докарантинних продажів [6]. Основні данні по оберту продукції та послуг наведено на рис. 1.

Саме така тенденціє і $€$ причиною пошуку інноваційного дифузного переосмислення роботи підприємств ресторанного господарства.

Згідно з науковим поглядом виокремлюють чотири рівні дифрузного управління підприємством ресторанного господарства.

Підприємстваресторанного бізнесупершого рівня розглядають організацію апарату управління як внутрішньо нейтральний елемент потенціалу, а роль керівника обмежують налагодженням випуску продукції, без огляду на проблеми конкурентоспроможності та задоволення потреб споживачів. Зайвими вважають зміну конструкції чи підвищення технічного рівня продукції, удосконалення структури й фрункцій відділу збуту та службу маркетингу, оскільки не беруться до уваги зміни ринкової ситуації та потреб споживачів. Ця позиція досить не актуальна і не підходить до сучасних реалій світу.

Підприємства ресторанного бізнесу другого рівня інноваційної дисрузності організації ресторанного господарства намагаються зробити виробничий елемент потенціалу «зовнішньо нейтральним». Це означає, що потенціал підприємства ресторанного бізнесу повинен повністю відповідати стандартам, встановленим його основними конкурентами.

Якщо керівники підприємства ресторанного бізнесу розуміють конкурентні переваги на ринку дещо інакше, ніж їхні основні суперники, та намагаються не обмежуватися тими загальними стандартами виробництва, що діють в галузі, то потенціал підприємства ресторанного бізнесу еволюціонує до третього рівня конкурентоспроможності. На таких підприємства ресторанного бізнесух виробнича складова потенціалу зазнає сильного впливу з боку складової управління, що сприяє її розвитку та удосконаленню.

Коли успіх у конкурентній боротьбі стає вже не стільки фрункцією виробництва, скільки функцією управління, та починає залежати від якості, ефрективності управління, організації виробництва, тоді підприємства ресторанного бізнесу досягають четвертого рівня інноваційної дисрузії організацій ресторанного господарства й опиняються попереду конкурентів протягом тривалого часу.

Нині потенціал більшості вітчизняних підприємств можна віднести до першого рівня. Однак

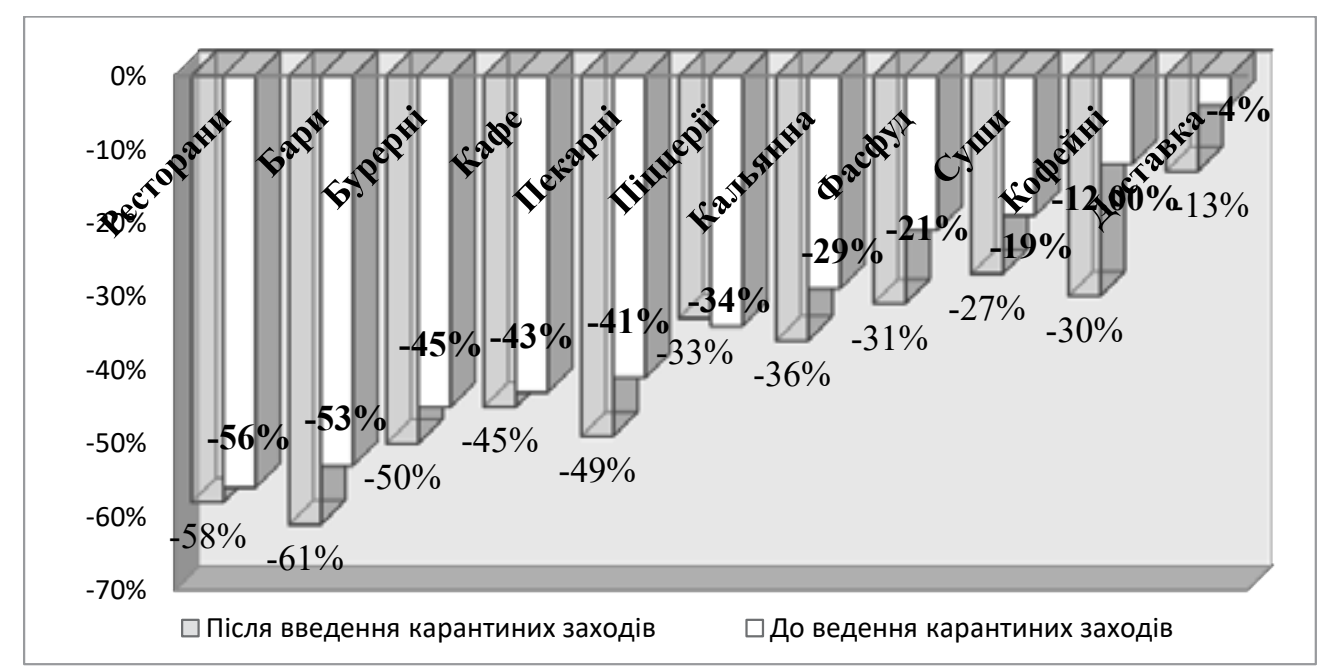

Рис. 1. Середня втрата обороту закладів ресторанного бізнесу Джерело: сорормовано автором на підставі [6] 
варто зазначити, що помітні й прогресивні зрушення в діяльності окремих підприємств, які тяжіють до третього і навіть до четвертого рівня інноваційної дифузії організації підприємства ресторанного господарства. Пандемія COVID-19 серйозно порушила глобальне споживання, змусивши людей не викреслювати старі звички та прийняти нові. Компанії, які прагнуть вийти 3 кризи в більш сильних позиціях, повинні виробити систематичне розуміння змін звичок. Для багатьох фрірм для цього потрібен новий процес виявлення та оцінки змін, перш ніж вони стануть очевидними для всіх [4].

Тобто, реалії суспільства вимагають застосування інноваційних заходів, щодо організацій управління підприємством ресторанного господарства. Виклики трьох локдаунів перевели світ на використання електронного спілкування. Через це змінилась і організація надання ресторанних послуг та і сам сучасний споживач став діджиталізований. Необхідні інноваційні заходи для дифузного перетворення організації підприємств ресторанного господарства наведено на рис. 2
Сьогодні весь світ знаходиться у стані пандемічного локдауну, тому економічні суб'єкти шукають ефективні засоби підтримки бізнеспозицій. Об'єктами уваги стали маркетинг відносин та якісні поліпшення сервісів, які дистанціювали відносини бізнесу 3 клієнтами через онлайн-платформи. Зростання трафріків пошукових систем, зокрема локальних онлайн-платорорм, спричиняють актуальність дослідження можливостей їхніх інструментів для маркетингових активностей [1].

Впроваження CRM-систем для зворотнього зв'язку є важливим напрямком впровадження оборонної програми інноваційної дифузної організації ресторанного господарства 3 елементами фокусування, оскільки передбачає можливість значно підвищити ефективність комплексу маркетингових комунікацій ресторану зі споживачами. Саме цей єлемент в сучасних карантиних обмеженнях є єдиним для виходу підприємств з кризи.

Впровадження CRM-системи для підприємств ресторанного господарства передбачає досягнення наступних цілей розвитку

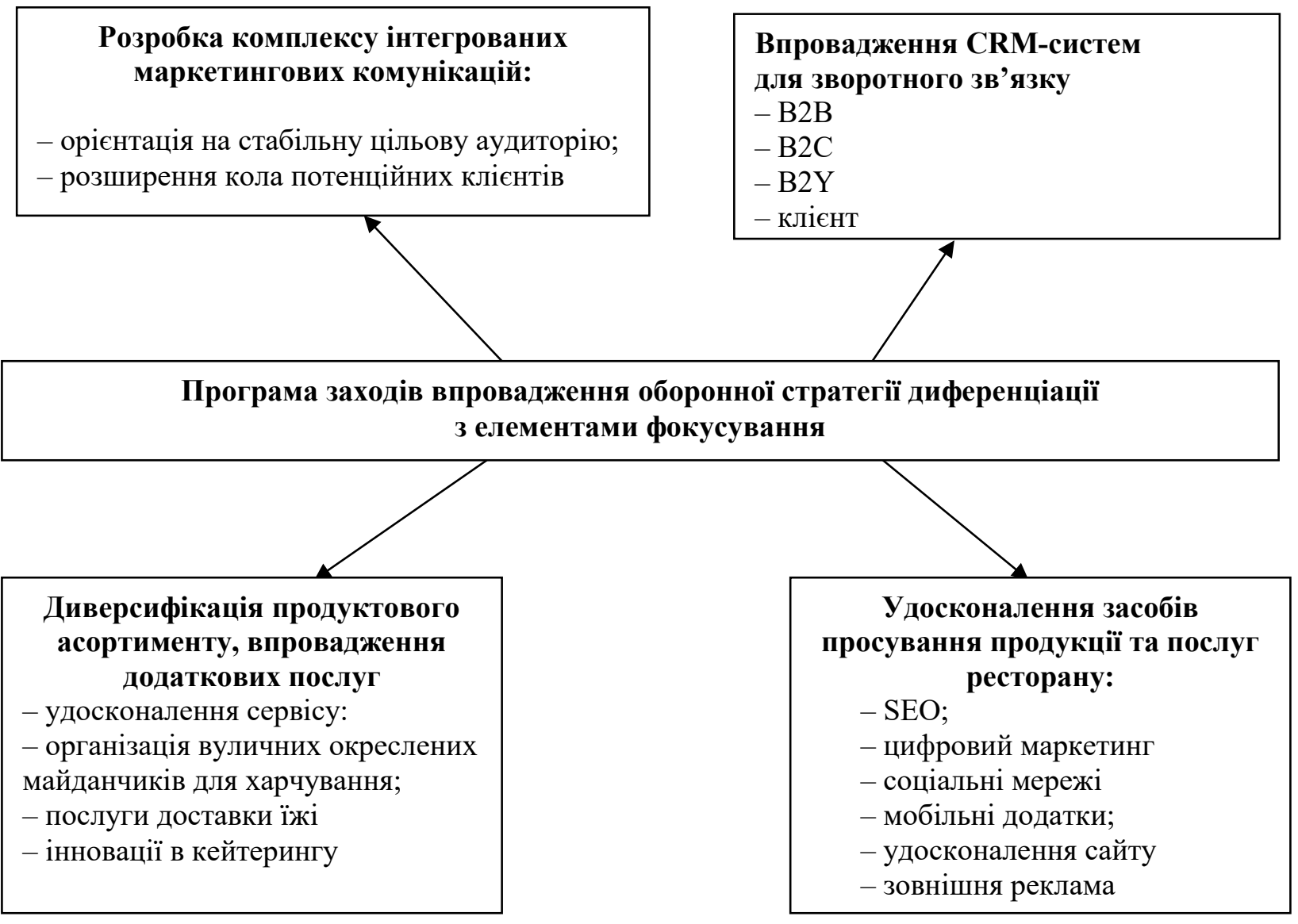

Рис. 2. Програма інноваційної дифузної організації ресторанного господарства з елементами фокусування Джерело: сфрормовано автором 
комплексу маркетингових комунікацій з його клієнтами:

- розробка комплексу інтегрованих марктеингових комунікацій (аналіз ринку, проведення оцінки основних бізнес-процесів, окреслення цільової аудиторії, вибір засобів просування продукції та послуг ресторану);

- впровадження CRM-системи Sugar для зворотнього зв'язку (збір первинної інфрормації, проведення оцінки основних бізнеспроцесів, пошук компанії-інтегратора, яка буде здійснювати впровадження CRM-системи, роботи з розгортання та налаштування нової CRM-системи, навчання персоналу та запуск CRM-системи в роботу);

- удосконалення закупівель та формування акційних програм для стимулювання збуту (визначення можливих напрямків впровадження акціний програм, фрормування системи цільових знижок, оцінка бюджету та есрективності акційних програм);

- удосконалення засобів просування продукції та послуг ресторану;

- диверсифрікація продуктового асортименту, впровадження додаткових послуг, удосконалення сервісу

Всі ці заходи є запорукою збереження нинішніх позицій на ринку та поступового виходу під- приємств ресторанного бізнесу з кризи. В Японії і інших розвинутих країнах світи під час карантинних обмежень почали використовувати роботизацію та самообслуговування. В Україні це поки що не можливо, але саме це дозволило залучити ще більшу кількість споживачів і охопити інший сегмент ринку. Поки про ці інноваційні дифузії в організації сучасних закладів ресторанного господарства говорити рано.

Висновки. Тобто, сучасний світ за рік перетворився в діджиталізоване суспільства. Ці нові виклики потребують від підприємств ресторанного бізнесу нововведення. Пережили два локдауни ті ресторани які мали свою інорормаційну систем управління, що допомогло швидко переозброїти свою організацію господарської діяльності. Впровадження CRM-систем наразі необхідний захід інноваційної дифрузії в організації ресторанного господарства. Цей зв'язок є важливим напрямком впровадження програми інноваційної дифрузної організації ресторанного господарства з елементами фокусування. І Оскільки передбачає можливість значно підвищити есрективність комплексу маркетингових комунікацій ресторану зі споживачами. Саме цей елемент в сучасних карантинних обмеженнях $\epsilon$ єдиним виходом підприємств з кризи.

\section{СПИСОК ВИКОРИСТАНИХ ДЖЕРЕЛ:}

1. Бовш Л.А., Гопкало Л.М., Тесля Ю.А. Геокарта клієнтського середовища в умовах ескалації пандемії. Ресторанно-готельний консалтинг. Інновації. 2020. Вип. 3. № 2. С. 33-35. URL: https://doi.org/10.31866/2 616-7468.3.2.2020.219691 (дата звернення: 02.04.2021).

2. Бунт рестораторов: как бизнес пытается сменить "запреты" на "рекомендации". URL: https://biz.liga.net/ keysy/prodovolstvie/opinion/bunt-restoratorov-kak-biznes-pytaetsya-smenit-zaprety-narekomendatsii (дата звернення: 12.04.2021).

3. Коваленко Л.Г. Асортиментна політика закладів ресторанного господарства України. Економіка та суспільство. 2016. № 5. С. 158-162.

4. Литвишко Л.О., Горбенко Ю.А. Адаптація бізнесу до нових реалій пандемії COVID-19. Матеріали $i$ всеукраїнської науково-практичної конференції «Управління та адміністрування в умовах протидії гібридним загрозам національній безпеці» В рамках реалізації проекту Erasmus+ «Академічна протидія гібридним загрозам» WARN 610133-EPP-1-2019-1-FI-EPPKA2-CBHE-JP. 2020. C. 65. URL: https://drive.google.com/ file/d/1k3PeCfr_7sJJogv8VydUQn4vwRAqT7xE/view 2 (дата звернення: 11.04.2021).

5. Пандемія COVID-19 та її наслідки у сфері туризму в Україні. «Дорожня карта конкурентоспроможного розвитку сорери туризму в Україні». URL: http://www.ntoukraine.org/assets/files/EBRD-COVID-19Report-UKR.pdf

6. Скільки втратили кафе і ресторани під час карантину - дослідження. Економічна правда. URL: https://www.epravda.com.ua/news/2020/06/10/661570/ (дата звернення: 02.04.2021).

\section{REFERENCES:}

1. Bovsh L.A., Gopkalo L.M., Tesla Yu.A. (2020) Heokarta kliientskoho seredovyshcha v umovakh eskalatsii pandemii [Geographic map of the client environment in an escalating pandemic]. Restaurant and hotel consulting. Innovations, no. 2, pp. 33-35. Available at: https: //doi.org/10.31866/2616-7468.3.2.2020.219691 (accessed 2 April 2021). 
2. Revolt of restaurateurs: how business tries to change "prohibitions" on "recommendations". Available at: https://biz.liga.net/keysy/prodovolstvie/opinion/bunt-restoratorov-kak-biznes-pytaetsya-smenit-zaprety-na rekomendatsii (accessed 12 April 2021).

3. Kovalenko L.G. (2016) Asortymentna polityka zakladiv restorannoho hospodarstva Ukrainy [Assortment policy of restaurants of Ukraine]. Economy and society, no. 5, pp. 158-162.

4. Litvishko L.O., Gorbenko Yu.A. (2020) Adaptatsiia biznesu do novykh realii pandemii COVID-19 [Adaptation of business to the new realities of the COVID-19]. Pandemic Proceedings of the All-Ukrainian scientific-practical conference "Management and administration in the context of combating hybrid threats to national security" In the framework of the Erasmus + project "Academic counteraction to hybrid threats", p. 65. URL: https://drive.google.com/ file/d/1k3PeCfr_7sJJogv8VydUQn4vwRAqT7xE/view 2 (accessed 11 April 2021).

5. The COVID-19 pandemic and its consequences in the field of tourism in Ukraine. "Roadmap for competitive development of tourism in Ukraine". Available at: http://www.ntoukraine.org/assets/files/EBRD-COVID-19-ReportUKR.pdf

6. How many cafes and restaurants lost during quarantine - research. Economic truth. Available at: https://www.althoughda.com.ua/news/2020/06/10/661570/ (accessed 02 April 2021). 